\title{
Phytochemical study and biological activities of Scurrula parasitica L (Loranthaceae) leaves
}

\author{
Kamal Ja' afar MUHAMMAD ${ }^{1,2}$ (D), Shajarahtunnur JAMIL ${ }^{1 *}$ (D) , Norazah BASAR 1 (D) \\ 1 Department of Chemistry, Faculty of Science, Universiti Teknologi Malaysia, 81310 Johor \\ Bahru, Johor, Malaysia. \\ 2 Chemistry Advanced Research Center, Sheda Science and Technology Complex, 186 Garki, Abuja, \\ Nigeria. \\ * Corresponding Author. E-mail address: shaja@kimia.fs.utm.my (S.J.); Tel. +6075534156
}

Received: 18 September 2018 / Revised: 04 December 2018 / Accepted: 07 December 2018

\begin{abstract}
Chemical constituents of Scurrula parasitica leaves from Loranthaceae family and some biological activities have been studied. Cold extractions were carried out using $n$-hexane, ethyl acetate and methanol to obtain the crude extracts. Purification of the extracts led to the isolation of quercetin 1, quercitrin 2, kaempferol 3-O- $\alpha$-L-rhamnoside 3 , $(+)$-catechin 4, lupeol 5, lupeol palmitate $6, \beta$-sitosterol 7, squalene 8 , octacosane 9 , octadecane 10 and eicosane 11 . The in vitro antioxidant activity of the extracts and isolated compounds were evaluated. Compounds 1, 2, 3 and 4, together with ethyl acetate and methanol extracts exhibited effective antioxidant activities against DPPH, ABTS and FRAP assays, while $n$-hexane and other compounds were inactive. The ethyl acetate extract gave the highest tyrosinase percent inhibition value of $66.02 \%$, while quercetin gave the best result with tyrosinase percent inhibition value of $79.09 \%$. All extracts and isolated compounds showed weak activity on antimicrobial inhibition assay with the exception of quercetin which exhibited moderate activity against Pseudomonas aeruginosa with MIC and MBC value of $250 \mu \mathrm{g} / \mathrm{mL}$.
\end{abstract}

KEYWORDS: Quercetin; Scurrula parasitica; loranthaceae; antityrosinase, antioxidant.

\section{INTRODUCTION}

Loranthaceae is the leading pantropical plant family with 77 genera and about 1000 species spread across the world. They are woody flowering plants generally known as mistletoes which are found growing in Africa, Asia, Europe, Australia, South America and New Zealand [1]. The medicinal application of species from Loranthaceae have been rationalized based on the ethnomedicinal uses, isolation and identification of the bioactive compounds in the classes of flavonoids, phenols, glycosides, alkaloids and triterpenes. Several plants belonging to this family have been widely used in traditional medicine as therapeutic herbs. For instance, the tea made from Loranthaceae plants is believed to cure body pain and bone fracture [2]. In Saudi Arabia, fresh stem of Tapinanthus globiferus are administered orally to all kind of livestock for fever treatment and removal of placenta after parturition [3]. In Europe, various preparations of Viscum album in the form of injectable extracts are sold as Abnobaviscum, Helixor, Iscador, and as fermented V. album and are used to treat arthritis, epilepsy, hypertension and infertility [4]. In Africa, infusion of the Loranthaceae leaves is used in the treatment of abdominal pains, diabetes, fever, and urinary tract infections [2]. The genus Scurrula is a prevalent parasitic plant found in Asia and has been used as traditional medicinal herbs for cancer, hypertension, microbial infections and as antioxidant [5]. In addition, species of genus Scurrula were used in Indonesia and Java to treat cancer and as infusion for fatigue [6]. The leaves and stems of Scurrula parasitica have been reported to be used as antioxidants, cardiotonic and antineoplastic agents in the southern part of China [7].

Previous phytochemical study carried out on the leaves of the Southern China Scurrula parasitica growing on Nerium indicum, reported the isolation of a new hydroxylated lupeol-based triterpenoid ester (3ß,7 3 )-7-hydroxyl-lup-20(29)-en-3-yl hexadecanoate [8]. In addition, Quan-Yu et al. [9] have successfully investigated the methanol extract of Scurrula parasitica leaves and reported the isolation of a new triterpenoid ester 7 $\beta$-hydroxyl-hop-22(29)-en-3 $\beta$-O-palmitate. Our previous study showed that the methanol and ethylacetate extracts of Globimetula braunii, a Loranthaceae parasitic plant from Africa have a significant

How to cite this article: Muhammad KJ, Jamil S, Basar N. Phytochemical study and biological activities of Scurrula parasitica L (Loranthaceae) leaves. J Res Pharm. 2019; 23(3): 522-531. 
antioxidant activity [10]. Meanwhile, two lactone derivatives, (1R,5S,7S)-7-[2-(4-hydroxyphenyl)ethyl]-2,6dioxabicyclo[3.3.1]nonan-3-one and dodoneine were identified from Globimetula braunii [11]. In our continuing chemical investigation of bioactive compounds from Loranthaceae plants, we have isolated quercetin 1, quercitrin 2, kaempferol 3-O- $\alpha$-L-rhamnoside 3, $(+)$-catechin 4, lupeol 5, lupeol palmitate 6, $\beta$-sitosterol 7 squalene 8, octacosane 9, octadecane 10 and eicosane 11 (Figure 1) from the leaves part of Scurrula parasitica. To date, there is no report on the isolation of kaempferol 3-O- $\alpha$-L-rhamnoside 3, squalene 8, octacosane $\mathbf{9}$, octadecane 10 and eicosane 11, and evaluation of tyrosinase inhibition activity from S. parasitica. We report here from this species, the isolation, structural elucidation and the antioxidant, antityrosinase and antimicrobial activities of the extracts and isolated compounds.<smiles>O=c1c(O)c(-c2ccc(O)c(O)c2)oc2cc(O)cc(O)c12</smiles>

(1)<smiles>C[C@H]1c2c(O)cc(O)cc2O[C@H](c2ccc(O)c(O)c2)[C@@H]1O</smiles>

(4)

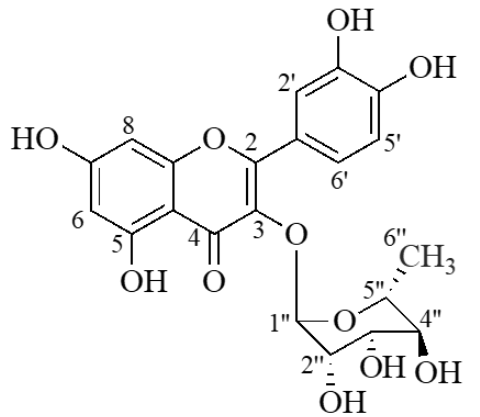

(2)

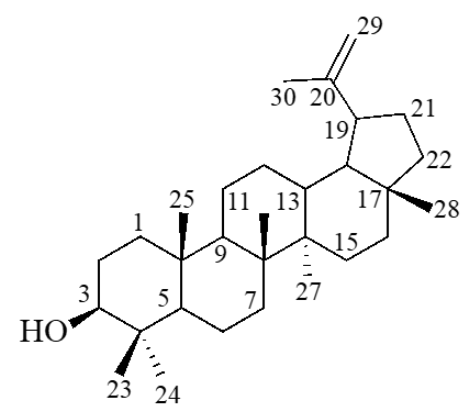

(5)

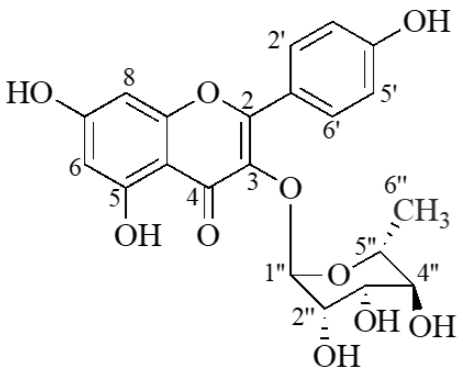

(3)

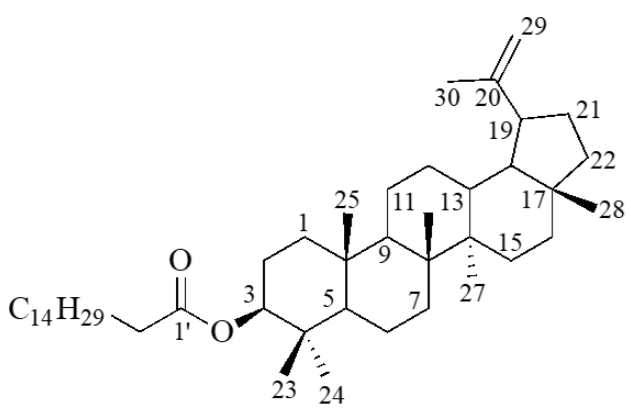

(6)<smiles>CCC(CC[C@H](C)[C@]12CCC3C4CC=C5C[C@@H](O)CC(C)C5(C)C4CC[C@]31CC2)C(C)C</smiles>

(7)

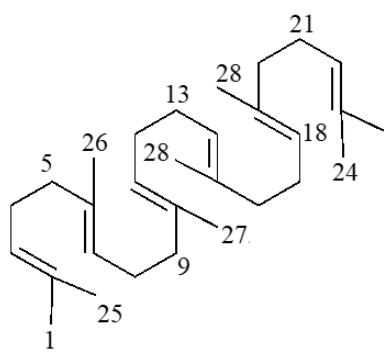

(8)

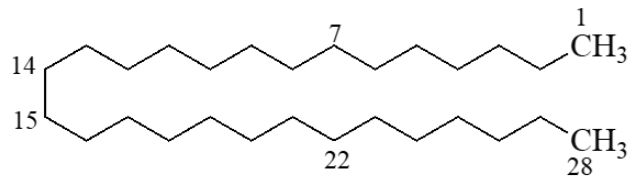

(9)

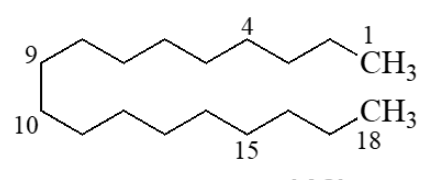

(10)

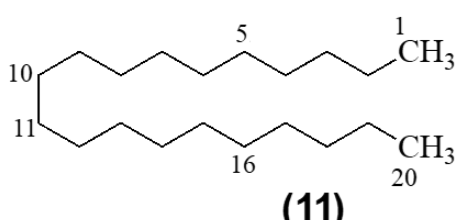

(11)

Figure 1. Chemical structures of compounds 1-11 isolated from the leaves of S. parasitica. 


\section{RESULTS AND DISCUSSION}

Phytochemical investigation of the leaves extract of Scurrula parasitica growing on P. pinnata yielded 11 known compounds. The chemical structures of these compounds have been identified as quercetin 1 [12], quercitrin 2 [13], kaempferol 3-O- $\alpha$-L-rhamnoside 3 [14], (+)-catechin 4 [15], lupeol 5 [16], lupeol palmitate 6 [17], $\beta$-sitosterol 7 [18], squalene 8 [19], octacosane 9 [20], octadecane 10 [21] and eicosane 11 [22] on the basis of spectral analysis (1D, 2D NMR and MS) and comparison with reported data. Table 1 summarized the complete analysis of ${ }^{1} \mathrm{H}$ and ${ }^{13} \mathrm{C}$ NMR of compounds $1,2,3$ and 4 . The in vitro assays on the crude extracts $(n$ hexane (SPPPH), EtOAc (SPPPE) and $\mathrm{MeOH}(\mathrm{SPPPM})$ ) and isolated compounds from the leaves of Scurrula parasitica were performed for antioxidant, antityrosinase and antimicrobial activities. The results are compiled in Table 2. It is important to point out that, this work represents the first report on the antityrosinase activity from the chemical point of view of this mistletoe species. The antioxidant activity was determined using DPPH, ABTS and FRAP assays. Our obtained data showed that SPPPE and SPPPM possessed potent antioxidant effect. Quercetin 1 exhibited strong antioxidant activity comparable to the positive controls used. The higher reducing value obtained for quercetin was previously suggested by Strube et al. [23]. The result demonstrated the higher oxidation potential of quercetin than quercitrin and kaempferol-3-O- $\alpha$-Lrhamnoside. This is due to the importance of the catechol structure in the B ring which significantly enhances the antiradical activity as well as reducing the 3-hydroxyl group on the saturated $\mathrm{C}$ ring adjacent to a carbonyl group. The carbonyl group (4 oxo function) and 2,3 double bond in $\mathrm{C}$ ring support electron delocalization between the $\mathrm{A}$ and $\mathrm{B}$ ring and stabilize the aryloxyl radical after hydroxy donation. This implies that the presence of the 2,3 double bond in combination with carbonyl group (4 oxo function) in the C-ring could be beneficial for radical stabilization and strengthen the activity of the flavonols [24]. The result is in accordance with the previous work, in which a good antioxidant activity was shown by the crude extract of S. parasitica growing on different hosts plants [6]. In contrast, the weak antioxidant activity observed for SPPPH extract and the tested triterpenes could be described by the presence of non-polar compounds which have no ability to act as reducing agent [25].

SPPPE exhibited a significant antityrosinase percent inhibition of $66.03 \%\left(\mathrm{IC}_{50}=0.21 \pm 0.03 \mathrm{mM}\right)$. However, SPPPM and SPPPH inhibited the L-DOPA oxidation at a percent inhibition less than $50.00 \%$. Quercetin 1, lupeol 5 and $\beta$-sitosterol 7 showed the highest inhibition activities with percent inhibition of $79.09 \%, 52.77 \%$ and $50.00 \%$ ( $\mathrm{IC}_{50}$ values of $0.13 \pm 0.12 \mathrm{mM}, 0.44 \pm 0.30 \mathrm{mM}$ and $0.53 \pm 0.70 \mathrm{mM}$ ) respectively. Other isolated compounds were found to have weak to very low percent inhibition. The tyrosinase percent inhibition of the isolated compounds ranged from $19.60-79.09 \%$ lower than that of the positive control, kojic acid $\left(83.81 \%, \mathrm{IC}_{50}=0.12 \pm 0.31 \mathrm{mM}\right)$. Comparing the percent inhibition trends of all the tested compounds, it can be deduced that the presence of 3-hydroxy-4-keto moiety of quercetin played an important role in eliciting activity for the competetive inhibition of L-DOPA by tyrosinase enzymes through their power to chelate the copper in the active position, resulting to irreversible inactivation of tyrosinase [26]. This is in conformity with the previous finding of the tyrosinase inhibition activity carried out on some naturally and synthetic tyrosinase inhibitors [26]. The result showed that quercetin exhibited a significant tyrosinase inhibition activity with $\mathrm{IC}_{50}$ value of $0.07 \mathrm{mM}$ (Kojic acid, $\mathrm{IC}_{50}=0.014 \mathrm{mM}$ ) [26]. However, the flavonol glycosides, were found to exhibit weak or no inhibitory activity due to lack of free hydroxyl group at C-3 position which act as a significant part in copper chelation [26]. Previous work also reported dose-dependent tyrosinase inhibitory effect of triterpenoids such as betulin $\left(\mathrm{IC}_{50}=1.44 \pm 0.03 \mathrm{mM}\right)$ and lupeol $\left(\mathrm{IC}_{50}=2.24 \pm 0.12 \mathrm{mM}\right)$, which is comparable to that of the standard used kojic acid $\left(\mathrm{IC}_{50}=0.68 \pm 0.11 \mathrm{mM}\right)$ [27]. Therefore, the activity observed in lupeol 5 and $\beta$-sitosterol 7 suggested that triterpenoids can be considered as potential agents for treatment of pigmentation disorders. The antimicrobial activity of all the tested crude extracts and isolated compounds displayed weak to inactive inhibition against all the tested Gram-positive, Gram-negative and fungal strain tested with MIC values ranging from $500->1000 \mu \mathrm{g} / \mathrm{mL}$. Only quercetin 1 showed moderate inhibition against Pseudomonas aeruginosa (MIC and MBC value $250 \mu \mathrm{g} / \mathrm{mL}$ ). The weak antimicrobial activity of the extracts is in justification with the antibacterial assay carried out on acetone/water $(8: 2 \mathrm{v} / \mathrm{v})$ extract of Malaysian S. ferruginea against Gram-positive and Gram-negative bacteria. The results showed that all the tested extracts including stem, leaf and flower possessed weak antimicrobial activities against Staphylococcus aureus, Bacillus subtilis and Escherichia coli. The moderate inhibition $(225 \mu \mathrm{g} / \mathrm{mL})$ observed in the study was against Pseudomonas putida which was not tested in this study [28]. The significance of the mistletoes in ethnopharmacology gave them the name "cure all" and this is supported by the scientific informations recorded in the biological studies of some of the crudes and purified extracts [2]. 


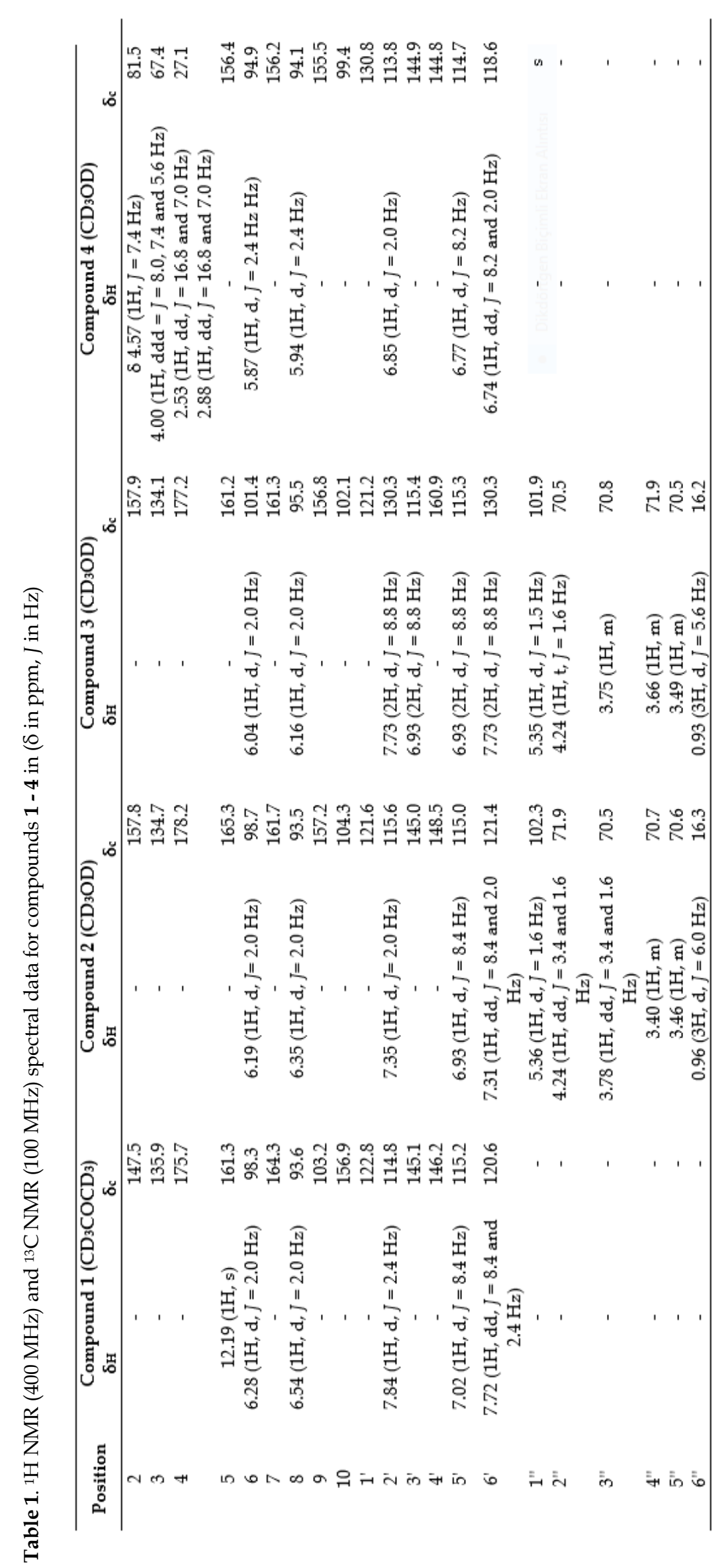


Table 2. Free radical scavenging (DPPH, $\mathrm{ABTS}^{\bullet+}$ and FRAP) and tyrosinase inhibitory activities of leaf extracts and isolated compounds of S. parasitica L.

\begin{tabular}{|c|c|c|c|c|c|}
\hline $\begin{array}{l}\text { Extracts/ } \\
\text { Compounds }\end{array}$ & $\begin{array}{c}\text { DPPH } \\
\mathrm{IC}_{50}(\mu \mathrm{g} / \mathrm{ml})\end{array}$ & $\begin{array}{c}\text { ABTS } \\
\mathrm{IC}_{50}(\mu \mathrm{g} / \mathrm{ml})\end{array}$ & $\begin{array}{c}\text { mM FRAP equivalent to } \\
\text { FeSO }_{4} .7 \mathrm{H}_{2} \mathrm{O}(1.0 \mathrm{Mm})\end{array}$ & $\begin{array}{l}\text { TIA Inhibition } \\
(\mathrm{I} \%) \text { at } 100 \mu \mathrm{g} / \mathrm{mL}\end{array}$ & $\begin{array}{c}\text { TIA } \\
\text { IC }_{50}(\mathrm{mM}) \\
\end{array}$ \\
\hline \multicolumn{6}{|l|}{ Extracts } \\
\hline n-Hexane & 383.10 & $>5000$ & ND & 44.60 & ND \\
\hline Ethyl Acetate & 30.15 & 392.30 & $3.56 \pm 0.07$ & 66.03 & $0.21 \pm 0.03$ \\
\hline Methanol & 30.71 & 386.30 & $4.80 \pm 0.10$ & 48.44 & ND \\
\hline \multicolumn{6}{|l|}{ Pure } \\
\hline $\begin{array}{l}\text { Compounds } \\
\text { (1) }\end{array}$ & 0.82 & 312.01 & $3.94 \pm 0.49$ & 79.09 & $0.13 \pm 0.12$ \\
\hline (2) & 22.48 & 410.90 & $3.74 \pm 0.07$ & 49.82 & ND \\
\hline (3) & 6.35 & 504.60 & $2.70 \pm 0.09$ & 47.94 & ND \\
\hline (4) & 8.49 & 513.50 & $3.44 \pm 0.02$ & 31.53 & ND \\
\hline (5) & $>1000$ & NT & NT & 52.77 & $0.44 \pm 0.30$ \\
\hline (6) & $>1000$ & NT & NT & 19.60 & ND \\
\hline (7) & $>1000$ & NT & NT & 50.00 & $0.53 \pm 0.70$ \\
\hline (8) & $>1000$ & NT & NT & NT & NT \\
\hline (9) & $>1000$ & NT & NT & NT & NT \\
\hline (10) & $>1000$ & NT & NT & NT & NT \\
\hline (11) & $>1000$ & NT & NT & NT & NT \\
\hline \multicolumn{6}{|l|}{ Standard } \\
\hline BHA & 11.30 & 317.70 & $5.69 \pm 0.42$ & NA & NA \\
\hline Trolox & 0.90 & 354.01 & NT & NA & NA \\
\hline $\mathrm{AA}$ & NT & NT & $5.06 \pm 0.07$ & NA & NA \\
\hline Kojic Acid & NA & NA & NA & 83.81 & $0.12 \pm 0.31$ \\
\hline
\end{tabular}

All values are expressed as mean $\pm S D$ for three replicates experiment. $\mathrm{IC}_{50}$ is defined as the concentration sufficient to obtain $50 \%$ of the maximum scavenging capacity; ND = Not Determined, NT =Not tested, NA =Not applicable, TIA = tyrosinase inhibitory activities

\section{CONCLUSION}

The information in this studies has demonstrated the antioxidant, antityrosinase and antimicrobial potential of Scurrula parasitica and thus provide some logical evidence supporting the traditional uses and medicinal beliefs by different ethnic groups in Asia and other parts of the world for alleviating skin disorders and as antioxidants based on the information in the literatures. To the best of our knowledge, this is the first report on the isolation of kaempferol 3-O- $\alpha$-L-rhamnoside 3, squalene 8, octacosane $\mathbf{9}$, octadecane 10 and eicosane 11, and evaluation of tyrosinase inhibition activity from $S$. parasitica.

\section{MATERIALS AND METHODS}

\subsection{General experimental procedures}

The 1D and 2D NMR spectra were recorded on a Brüker Avance $400 \mathrm{MHz}$ spectrometer. Chemical shifts were reported in ppm relative to tetramethylsilane (TMS) in deuterated solvents; chloroform $\left(\mathrm{CDCl}_{3}\right)$, acetone $\left(\mathrm{CD}_{3} \mathrm{COCD}_{3}\right)$ or methanol $\left(\mathrm{CD}_{3} \mathrm{OD}\right)$. The IR spectra were recorded on Perkins Elmer series 1600 spectrophotometer ( $\mathrm{KBr}$ pellet for solid and $\mathrm{NaCl}$ discs for liquid samples). The ultraviolet (UV) spectra were measured on Shimadzu UV 1601PC spectrophotometer. Gas chromatography (GC) analysis was carried out on Hewlett Packard HP6890 and equipped with an Ultra-1 capillary column. The Gas Chromatography-Mass spectrometry (GCMS) analysis were recorded using Wiley Library Software in a similar capillary condition with GC except for the oven temperature program in which the temperature was programmed at $50^{\circ} \mathrm{C}(5 \mathrm{~min})$, then $5^{\circ} \mathrm{C} / \mathrm{min}$ to $300^{\circ} \mathrm{C}(5 \mathrm{~min})$. Mass spectra were on a Finnigan-MAT-95 mass spectrometer from the Chemistry Department, National University of Singapore. Thin layer chromatography (TLC) was performed on $0.20 \mathrm{~mm}$ precoated silica gel aluminum sheets (Merck Kieselgel $60 \mathrm{~F}_{254}$ ). The spots on TLC were detected by ultraviolet (UV) illumination at $254 \mathrm{~nm}$ and $365 \mathrm{~nm}$ and sprayed with vanillin sulphuric acid, before being heated on a hot plate. Vacuum liquid chromatography (VLC) was performed using $\mathrm{Merck}^{\mathrm{SiO}} \mathrm{S}_{2}(230-400$

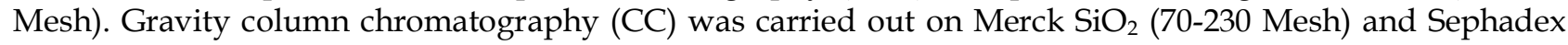
LH-20, while preparative thin layer chromatography (PTLC) was conducted using $1 \mathrm{~mm}$ thin glass plate of Merck $\mathrm{SiO}_{2} 60 \mathrm{~F}_{254}(20 \times 20 \mathrm{~cm})$. All solvents and reagents used were of general purpose and analytical grade. 


\subsection{Plant material}

Fresh leaves of S. parasitica parasitizing on P. pinnata were collected from Universiti Teknologi Malaysia (UTM), Southern Malaysia (Latitude N 10 33' 54.9", Longitude E 7o 103', 29.2") in August 2016. A voucher specimen was authenticated by Dr. Shamsul Khamis, a plant botanist and deposited at the Department of Landscape Architect, Faculty of Design and Architecture, Universiti Putra Malaysia, (UPM) under the No SK2800/17 and SK28001/17 for S. parasitica and P. pinnata, respectively.

\subsection{Extraction and isolation}

The powdered leaves $(1.45 \mathrm{~kg})$ of $S$. parasitica was extracted using cold extraction method sequentially with solvents of different polarity starting with $n$-hexane, EtOAc and $\mathrm{MeOH}$ for three days each with shaking at room temperature to yield the crude extracts, $n$-hexane (SPPPH: 27 g, 1.87\%), EtOAc (SPPPE: 32 g, 2.20\%) and $\mathrm{MeOH}$ (SPPM: $45 \mathrm{~g}, 3.10 \%)$. Quercetin 1 (8 $\mathrm{mg} \mathrm{0.03 \% )}$ was isolated as yellow powder with $\mathrm{R}_{f} 0.56(n-$ Hexane: EtOAc, 2:3) and m.p 300-302 ${ }^{\circ} \mathrm{C}$ from SPPPE by repeated CC over SiO2 with $n$-hexane: EtOAc as eluents. Purification process of SPPPM using VLC $\left(\mathrm{SiO}_{2} 600 \mathrm{~g}, 10.0 \mathrm{~cm} \times 10.0 \mathrm{~cm}\right)$ with $\mathrm{CHCl}_{3}: \mathrm{EtOAc:MeOH}$ as eluents in stepwise gradient followed by $\mathrm{CC}$ over $\mathrm{SiO}_{2}$ resulted in the isolation of quercitrin $2(7 \mathrm{mg}, 0.02 \%)$ as a yellow solid; $\mathrm{R}_{f} 0.62\left(\mathrm{CHCl}_{3}: \mathrm{MeOH}, 4.2: 0.8\right)$ and m.p 176-178 ${ }^{\circ} \mathrm{C}$, kaempferol 3-O- $\alpha$-L-rhamnoside 3 (7.5 $\mathrm{mg}, 0.02 \%)$ as a yellow powder; $\mathrm{R}_{f} 0.65\left(\mathrm{CHCl}_{3}: \mathrm{MeOH}, 4.2: 0.8\right)$ and $\mathrm{m} . \mathrm{p} 171-174{ }^{\circ} \mathrm{C}$, and (+)-catechin $4(9.2 \mathrm{mg}$, $0.02 \%)$ as a pale brown powder with m.p. $174-176^{\circ} \mathrm{C}$ and $\mathrm{R}_{f}$ value of 0.45 in $n$-hexane: EtOAc (1:4). Purification of the $n$-hexane extract $(\mathrm{SPPPH}, 27 \mathrm{~g})$ by VLC over $\mathrm{SiO}_{2}(600 \mathrm{~g}, 10.0 \mathrm{~cm} \times 10.0 \mathrm{~cm})$ with $n$-hexane: $\mathrm{CHCl}_{3}: \mathrm{EtOAc}$ as eluents in stepwise gradient followed by $\mathrm{CC}$ over $\mathrm{SiO}_{2} n$-hexane: EtOAc yielded lupeol 5 (28 mg, $\left.0.10 \%\right)$ as a white powder; $\mathrm{R}_{f} 0.67$ ( $n$-Hexane: EtOAc, 4:1) and m.p. $214-216^{\circ} \mathrm{C}$, lupeol palmitate $6(243 \mathrm{mg}, 0.9 \%)$ as white waxy solid; $\mathrm{R}_{f} 0.23$ ( $n$-Hexane:Et $\left.\mathrm{H}_{2} \mathrm{O}, 4.6: 0.4\right)$ and $\mathrm{m} . \mathrm{p} 79-81^{\circ} \mathrm{C}, \beta$-sitosterol $7(174 \mathrm{mg}, 0.64 \%)$ as white crystalline needles; $\mathrm{R}_{f} 0.45$ ( $n$-Hexane: EtOAc, 4.2:0.8) and m.p 132-134 ${ }^{\circ} \mathrm{C}$, squalene 8 and octacosane $9,(151 \mathrm{mg}, 0.56 \%)$ as white waxy powder with $\mathrm{R}_{f} 0.78$ ( $n$-Hexane: EtOAc, 4.9:0.1), and octadecane 10 and eicosane 11 (34 mg, 0.13\%) as white waxy powder with $R_{f} 0.78$ ( $n$-Hexane: EtOAc, 4.9:0.1).

\subsection{Solvent and chemicals}

Antioxidant: Analytical grade butylated hydroxyanisole (BHA), 6-Hydroxy-2,5,7,8-tetramethylchroman2-carboxylic acid (Trolox), 2,2-diphenyl-1-picrylhydrazyl (DPPH) and 2,2'-azino-bis (3-ethylbenzothiazoline6-sulphonic acid) (ABTS) were purchased from Sigma Aldrich. Ascorbic acid (AA) was purchased from Goodrich Chemical Enterprice (GCE), while sodium acetate trihydrate, ferric sulphate, 2,4,6-tripyridyl-striazine (TPTZ) and potassium persulfate were purchased from Fluka. All absorbances were measured using microplate reader EPOCH (Bio Tek). Antimicrobial: Nutrient agar (NA), sabouraud dextrose agar (SDA), Nutrient broth (NB), sabouraud dextrose broth (SDB), streptomycin sulphate and nystatin were obtained from Oxoid (Italy). All bacterial and fungi strains were purchased from Mutiara Saintifik Sdn. Bhd. (Malaysia). The bacterial and fungi strains were cultured and preserved in LB glycerol stock at $-20^{\circ} \mathrm{C}$ prior to use. Antityrosinase: Kojic acid, mushroom tyrosinase, L-tyrosinase-3,4-dihydroxyl-L-phenyla- lanine (L-DOPA) were purchased from Sigma Aldrich.

\subsection{Antioxidant activities}

\subsubsection{DPPH radical scavenging assay}

The effect of the samples on DPPH radical scavenging activity were measured according to technique shown by Najihah et al. [29] with slight modification. DPPH reagents $(100 \mu \mathrm{L})$ were added to the samples (100 $\mu \mathrm{L}$ ) with concentration ranging from $1000-10 \mu \mathrm{g} / \mathrm{mL}$ in methanol acquired from serial dilution. The DPPH methanol solution was kept for each microplate and used as control while the radical scavenging effect was observed and compared with butylated hydroxyanisole (BHA) and trolox as the references. The reaction was allowed to incubate for 30 minutes in the dark at room temperature, the absorbance of the resulting solutions were measured at $517 \mathrm{~nm}$. DPPH free radical scavenging activity in percentage (\%) antioxidant was calculated using the formula: 
$\%$ DPPH Scavenging $=\frac{A_{\text {blank DPPH }}-A_{\text {sample }}}{A_{\text {blank DPPH }}} \times 100$

$$
* \mathrm{~A}_{\text {Sample }}=\mathrm{A}_{\text {sample }}-\mathrm{A}_{\text {bank DPPH }}
$$

Where $\mathrm{A}_{\text {blank DPPH }}$ is the absorbance of DPPH reagent with methanol and $\mathrm{A}_{\text {sample }}$ is the absorbance of the test compound with $\mathrm{DPPH}$ reagent. The $\mathrm{SC}_{50}$ value was determined as the concentration of each sample required to give $50 \%$ of the absorbance revealed by the control.

\subsubsection{ABTS radical scavenging assay}

ABTS assay was determined by method described by Zou et al. [30] with slight modification. Concentrations of 7 and $4.9 \mathrm{mM}$ were respectively obtained by dissolving the ABTS and potassium persulfate in distilled water. The two solutions were equally mixed and kept for 12 to 16 hours in dark at room temperature. Distilled water was added repeatedly to the ABTS solution to obtained an absorbance of 0.7 at $734 \mathrm{~nm}$. The ABTS solutions $(190 \mu \mathrm{L})$ and sample solutions $(10 \mu \mathrm{L})$ were added to 96-well plates. The mixture was allowed to react in dark at room temperature for 30 minutes and the absorbance was recorded at $734 \mathrm{~nm}$. Percentage inhibition of ABTS radical was calculated as follows.

$$
\begin{gathered}
\text { (\%) ABTS Scavenging }=\frac{\mathrm{A}_{\text {blank ABTS }}-\mathrm{A}_{\text {sample }}}{\mathrm{A}_{\text {blank ABTS }}} \times 100 \\
* \mathrm{~A}_{\text {Sample }}=\mathrm{A}_{\text {ABTS }}+\mathrm{A}_{\text {Sample }}
\end{gathered}
$$

Where $\mathrm{A}_{\text {blank ABTS }}$ is the absorbance of ABTS solution with methanol and Asample is the absorbance of the test samples with ABTS solution.

\subsubsection{Ferric reducing antioxidant potential (FRAP) Assay}

FRAP assay was measured according to technique described by Channarong et al. [31] and Shahwar et al. [32] with slight modification. Acetate buffer $(300 \mathrm{mM})$, TPTZ (2,4,6-tripyridyl-s-triazine) $10 \mathrm{mM}$ in $\mathrm{HCl}$ $(40 \mathrm{mM})$ and $\mathrm{FeCl}_{3} \cdot 6 \mathrm{H}_{2} \mathrm{O}(20 \mathrm{mM})$ were mixed in the ratio of 10:1:1 to obtained the FRAP reagent. The FRAP reagent $(150 \mu \mathrm{L})$, methanol $(15 \mu \mathrm{L})$ and test sample $(0.5 \mu \mathrm{L})$ were added to the 96 -well plates. The reduction of ferric-tripyridyltriazine $\left(\mathrm{Fe}^{3+}-\mathrm{TPTZ}\right)$ complex to ferrous $\left(\mathrm{Fe}^{2+}\right)$ resulted in the development of absorption maximum with an intense blue coloration. The absorbance was then measured at $593 \mathrm{~nm}$ after water bath incubation at $37^{\circ} \mathrm{C}$ [33]. The solutions of the $\mathrm{FeSO}_{4} \cdot 7 \mathrm{H}_{2} \mathrm{O}$ ranging from 0.1 to $1.0 \mathrm{mM}$ in methanol was used to acquire the known $\mathrm{Fe}^{2+}$ concentration calibration curve. Antioxidant concentration of ferric-TPTZ reducing capacity corresponding to $(0.1$ to $1.0 \mathrm{mM}) \mathrm{FeSO}_{4} \cdot 7 \mathrm{H}_{2} \mathrm{O}$ was considered as the parameter equivalent concentration.

\subsection{Tyrosinase inhibition assay}

The in vitro tyrosinase inhibitory activity was determined according to method described by Likhitwitayawuid and Sritularak [34] and Promden et al. [35], with slight modification. All the tested samples were dissolve in DMSO and tested at concentraion of $100 \mu \mathrm{g} / \mathrm{mL}, 50 \mu \mathrm{g} / \mathrm{mL}, 25 \mu \mathrm{g} / \mathrm{mL}, 12.5 \mu \mathrm{g} / \mathrm{mL}$ and 6.25 $\mu \mathrm{g} / \mathrm{mL}$. The test reaction mixture comprised of each sample $(0.1 \mathrm{mg} / \mathrm{mL}, 40 \mu \mathrm{L})$, mushroom tyrosinase enzyme (100 units/mL, $40 \mu \mathrm{L})$ and L-DOPA solution $(2.5 \mathrm{mM}, 40 \mu \mathrm{L})$ in sodium phosphate buffer $(100 \mathrm{mM}$, $80 \mu \mathrm{L}, \mathrm{pH}$ 6.8) all added to a 96 -well plate. The reaction mixture $(200 \mu \mathrm{L})$ was incubated at $37^{\circ} \mathrm{C}$ for $10 \mathrm{~min}$, and the absorbance was monitored at $475 \mathrm{~nm}$. The absorbance of the same mixture with DMSO instead of sample was used as negetive control, while kojic acid, a known tyrosinase inhibitor was employed as positive control. The percentage inhibition was calculated using the formula:

Inhibition $(\%)=\left(\frac{\text { Absorbance (blank)-Absorbance (tyrosinase+sample }}{\text { Absorbance (blank) }}\right) \times 100$ 


\subsection{Antimicrobial activity}

The in vitro antimicrobial activity was carried out against two Gram-positive bacteria (Staphylococcus aureus ATCC29737 and Bacillus subtilis ATCC6633), two Gram-negative bacteria (Escherichia coli ATCC10536 and Pseudomonas aeruginosa ATCC9027) and a fungi (Aspergillus niger ATCC16888). The microbes were melted from the glycerol stock and cultured in NB and SDB for bacterial and fungal, respectively. The broth media were pre-incubated to promote the growth of microorganisms. NB $(8 \mathrm{~g} / \mathrm{L})$ and SDB $(8 \mathrm{~g} / \mathrm{L})$ were dissolved in distilled water. Broth Microdilution Assay: Minimum inhibition concentration (MIC) and minimum bacterial/fungal concentration (MBC/MFC) values were measured by the broth microdilution techniques according to method described by Gulluce et al. [36] and Murray et al. [37]. The MIC test were determined in a sterile 96 -well microliter plates. Each crude extract $(14.5 \mathrm{mg})$ and pure compounds $(3.6 \mathrm{mg})$ were separately dissolved in $\mathrm{MeOH}(2.0 \mathrm{~mL})$ to obtain a sample stock solution with concentration $1800 \mu \mathrm{g} / \mathrm{mL}$. A few wells were reserved in each plate for positive and negative controls. Sterile NB/SDB $(100 \mu \mathrm{L})$ which were used as diluents were added to each microliter plate well from $\mathrm{B}$ to $\mathrm{H}$ followed by the addition of samples stock (100 $\mu \mathrm{L}$ ) in the first two row (A and B). Twofold serial dilution of the mixture of sterile broth and stock samples $(100 \mu \mathrm{L})$ in row $\mathrm{B}$ was transferred to each well in order to obtain a concentration range from 1800 to 14.13 $\mu \mathrm{g} / \mathrm{mL}$. Each bacterium $(100 \mu \mathrm{L})$ and fungi $(100 \mu \mathrm{L})$ were added to each well such that the final volume in each plate was $200 \mu \mathrm{g} / \mathrm{mL}$. Streptomycin sulphate and nystatin were employed as positive controls for bacteria and fungi, respectively. The microplates of different samples were then incubated at $37^{\circ} \mathrm{C}$ for $24 \mathrm{hrs}$ for bacteria and $30^{\circ} \mathrm{C}$ for $48 \mathrm{hrs}$ for fungi. Microbial growth was indicated by the appearance of turbidity and a pellet at the base of the well. The last clear well was determined as MIC value which is the lowest concentration of the tested samples without visible signs of microorganism growth. In determining the (MBC/MFC) values, $10 \mu \mathrm{L}$ of the clear well containing mixture of tested samples and inoculums were pipetted and spread gently on the surface of the NA $(5 \mathrm{~mL})$ for bacteria and SDA $(5 \mathrm{~mL})$ for fungi in a petri dish $(90 \times$ $15 \mathrm{~mm}$ ) using glass rod. The plates were sealed and incubated upside down at $37^{\circ} \mathrm{C}$ for $24 \mathrm{hrs}$ (bacteria) and $30^{\circ} \mathrm{C}$ for $48 \mathrm{hrs}$ (fungi). The MBC/MFC was recorded as the lowest concentration of the sample at which $99 \%$ of the bacteria/fungi colony were killed after the incubation period.

\subsection{Statistical analysis}

Three replicates for each tested sample were used with data presented as mean \pm standard deviation. The statistical analysis was performed using SPSS for windows (version 21). Data obtained from biological analysis were analysed using one way ANOVA.

Acknowledgements: The authors would like to acknowledge Ministry of Higher Education (MOHE) for the financial support under Research University Grant number (QJ130000.2526.17H01) and the Faculty of Science, Universiti Teknologi Malaysia for providing the research facilities.

Author contributions: Concept - K.J.M., S.J.; Design - K.J.M., S.J.; Supervision - S.J., N.B; Resource - K.J.M.; Materials - K.J.M, S.J.; Data Collection and/or Processing - K.J.M., S.J.; Analysis and/or Interpretation - K.J.M., S.J., N.B.; Literature Search - K.J.M; Writing - K.J.M., S.J.; Critical Reviews - K.J.M., S.J., N.B.

Conflict of interest statement: The authors declared no conflict of interest.

\section{REFERENCES}

[1] Zakaria M, Mohd, MA. Traditional Malay Medicinal Plants. Fajar Bakti, Kuala Lumpur. 1994.

[2] Adesina SK, Illoh CH, Imoh IJ, Jacobs EI. African mistletoes (Loranthaceae); ethnopharmacology, chemistry and medicinal values: An update. Afr J Tradit Complement Altern Med. 2013; 10(4): 161-170. [CrossRef]

[3] Sher H, Alyemeni MN. Pharmaceutical important plants used in traditional system of Arab medicine for the treatment of livestock ailments in the kingdom of Saudi Arabia. Afr J Biotechnol. 2011; 10(45): 9153-9159. [CrossRef]

[4] Matthes H, Schad F, Buchward D, Schenk G. Endoscopic ultrasound-guided fine needle injection of $V$. album L. (mistletoe; Helixor M) in the therapy of primary inoperable pancreas cancer; a pilot study. Gastroenterol. 2005: 128(4): $433, \mathrm{~T} 988$.

[5] Lim YC, Rajabalaya R, Shirley HFL, Tennakoon KU, Quang-Vuong L, Idris A, Zulkipli IN, Keasberry N, David SR. Parasitic mistletoes of the genera Scurrula and Viscum: from bench to bedside. Molecules 2016; 21: E1048. [CrossRef] 
[6] Puneetha GK, Amruthesh KN. Phytochemical screening and in vitro evaluation of antioxidant activity of various extracts of Scurrula parasitica. Int J Pharm Biol Sci. 2016; 6(1): 77-86.

[7] Xiao YJ, Chen YZ, Chen BH, Chen JH, Lin ZX, Fan YL. Study on cytotoxic activities on human leukemia cell line HL60 by flavonoids extracts of Scurrula parasitica from four different host trees. China J Chinese Mat Med. 2008; 33(4): 427-432.

[8] Quan-Yu L, Fei W, Lei Z, Jie-Ming X, Lia P, Yong-Hong ZA. Hydroxylated lupeol-based triterpenoid ester isolated from the Scurrula parasitica Parasitic on Nerium indicum. Helv Chim Acta. 2015; 98: 627-632. [CrossRef]

[9] Quan-yu L, Fei W, Yong-Hong Z, Feng NI. Chemical constituents of Scurrula paracitica. China J Chinese Mat Med. 2016; 41(21): 3956-3561.

[10] Muhammad KJ, Shajarahtunnur J, Norazah B. Antioxidant activity of leaf extracts of Globimetula braunii (Engler) van Tiegh Parasitizing on Piliostigma thonningii and Parkia biglobosa. J Teknol. 2017; 79(5): 43-47.

[11] Muhammad KJ, Shajarahtunnur J, Norazah B, Mohd BB, Satyajit DS, Keith JF, Mathias OS. Lactones and flavonoids from the leaves of Globimetula braunii. Nat Prod Comm. 2017; 12(9): 1455-1458.

[12] Suganya T, Fumio I, Siriporn O. Antioxidant active principle isolated from Psidium guajava grown in Thailand. Sci Pharm. 2007; 75: 179-193. [CrossRef]

[13] Hasan SM, Ahmed IM, Mondal S, Uddin SJ, Masud MM, Sadhu SK, Ishibashi M. Antioxidant, antinociceptive activity and general toxicity study of Dendrophthoe falcata and isolation of quercitrin as the major component. Orient Pharm Exp Med. 2006; 6(4): 355-360.

[14] Lee SY, Young-Jin S, Shin MS, Cho YJ, Lee J. Antibacterial effects of afzelin isolated from Cornus macrophylla on Pseudomonas aeruginosa, A leading cause of illness in immunocompromised individuals. Molecules 2014; 19: 31733180. [CrossRef]

[15] Lin J, LinY. Flavonoids from the leaves of Loranthus kaoi (Chao). Kiu. J Food Drug Anal. 1999; 7(3): 185-190.

[16] Supaluk P, Puttirat S, Rungrot C, Somsak R, Virapong P. New bioactive triterpenoids and antimalarial activity of Diospyros rubra Lec. EXCLI J. 2009; 9: 1-10.

[17] Appleton RA, Enzell CR. Triterpenoids and aromatic components of deertongue leaf. Phytochemistry 1971; 10: 447 449. [CrossRef]

[18] Moghaddam FM, Farimani MM, Salahvarzi S, Amin G. Chemical constituents of dichloromethane extract of cultivated Satureja khuzistanica. Evid Based Complement Alternat Med. 2007;4(1):95-98. [CrossRef]

[19] Yang AM, Li H, Liu JL, Guo WJ, Wu R. Chemical constituents of Euphorbia altotibetica. Adv Mater Res. 2013; 634-638: 905-908. [CrossRef]

[20] Xu Y, Wei L. Chemical constituents of Astragalus chinensis L. China J Chinese Mat Med. 1995; 20(5): 297-320.

[21] Wang YN, Cai JY, Zhao L, Zhu E, Zhang DZ. Study on chemical constituents from Anoectochilus chapaensis, China J Chinese Mat Med. 2012; 35: 911-913.

[22] Komal R, Zubair M, Rasool N, Riaz M, Zia-Ul-Haq M, de Feo V. Phytochemical and biological studies of Agave attenuate. Int J Mol Sci. 2012; 13: 6440-6451. [CrossRef]

[23] Strube M, Haenen GRMM, Van Den Berg H, Bast A. Pitfalls in a method for the measurement of total antioxidant capacity. Free Radi Res. 1997; 26: 512-521.

[24] Yi-Zhhong C, Mei S, Jie X, Qiong L, Harold C. Structure-radical scavenging activity relationship of phenolic compounds from traditional Chinese medicinal plants. Life Sci. 2006; 78: 2872-2888. [CrossRef]

[25] Benzie IFF, Strain JJ. The ferric reducing ability of plasma as a measure of antioxidant power: the FRAP assay. Anal Biochem. 1996; 239: 70-76.

[26] Kim YJ, Uyama H. Review, tyrosinase inhibitors from natural and synthetic sources: structures, inhibition mechanism and perspective for the future. Cell Mol Life Sci. 2005; 62: 1707-1723. [CrossRef]

[27] Magid AA, Laurence V, Bontemps G, Lituudon M, Lavaud C. Tyrosinase inhibitors and sesquiterpene diglycosides from Guioa villosa. Planta Med. 2008; 74: 55-60. [CrossRef]

[28] Mohsen M, Neda A, Eko S, Shajarahtunnur J, Fadzilah AA, Shahpour K. Total phenolic content, antioxidant and antibacterial properties of Scurrula ferruginea extracts. J Teknol. 2014; 70(5): 65-72. 
[29] Hashim NM, Rahmani M, Ee GC, Sukari MA, Yahayu M, Amin MA, Ali AM, Go R. Antioxidant antimicrobial and tyrosinase inhibitiry activities of xanthones isolated from Artocarpus obtusus F.M. Jarret. Molecules 2012; 17: 60716082. [CrossRef]

[30] Zou Y, Chang SKC, Gu Y, Qian SY. Antioxidant activity and phenolic composition of lentils (Lens Culinaris var. Morton) extracts and its fractions. J Agric Food Chem. 2011; 59: 2268-2276. [CrossRef]

[31] Channarong A, Jutiviboonsuk A, Korsanan S. Total reducing antioxidant capacity of Thai herbal aromatic powder (Ya-Hom) measured by FRAP Assay. Thai Pharm Health Sci. J 2012; 7(3): 111-114.

[32] Shahwar D, Raza MA, Bukhari S, Bukhari G. Ferric reducing antioxidant power of essential oils extracted from Eucalyptus and Curcuma species. Asian Pac J Trop Biomed. 2012; S1633-S1636. [CrossRef]

[33] Seladji M, Bekhechi C, Beddou F, Dib H, Bendimerad N. Antioxidant activity and phytochemical screening of Nepeta nepetella aqueous and methanolic extracts from Algeria. J Appl Pharm Sci. 2014; 4(2): 012-016. [CrossRef]

[34] Likhitwitayawuid K, Sritularak. A new dimeric stilbene with tyrosinase inhibitory activity from Artocarpus gomezianus. J Nat Prod. 2001; 64: 1457-1459. [CrossRef]

[35] Promden W, Viriyabancha W, Monthakantirat O, Umehara K, Noguchi H, De-Eknamkul W. Correlation between the potency of flavonoids on mushroom tyrosinase inhibitory activity and melanin synthesis in melanocytes. Molecules 2018; 23: 1403. [CrossRef]

[36] Gulluce M, Sokmen M, Sahin F, Sokmen A, Adiguzel A, Ozer H. Biological activities of the essential oil and methanolic Micromeria frustica (L) Druce ssp seryllifolia (Bieb) PH Davis plants from the eastern Anatolia region of Turkey. J Sci Food Agric. 2004; 84: 735 - 741.

[37] Murray PR, Baron EJ, Pfaller MA, Tenover FC, Yolken RH. Manual of clinical microbiology. 7th Ed.; ASM: Washington DC, USA.

This is an open access article which is publicly available on our journal's website under Institutional Repository at http://dspace.marmara.edu.tr. 